\title{
CHILDREN - THE FUTURE OF THE KARELIAN LANGUAGE? CASE STUDY IN A KARELIAN VILLAGE
}

\author{
Sanna-Riikka Knuuttila \\ University of Eastern Finland
}

\begin{abstract}
This article deals with the knowledge of the Karelian language of school children living in a Karelian village. Karelian is an endangered language and it is said that it is a language of old people, that is why I was interested in children's knowledge of Karelian. The aim is consider how the children self-estimate their ability to speak, understand, read or write Karelian. This study shows that Karelian children do somehow know their heritage language. But to become skilful Karelian speakers children need plenty of help and support from their parents, teachers and from the community.
\end{abstract}

Keywords: endangered language, revitalization, Karelian

\section{Introduction}

This article deals with the knowledge of the Karelian language of school children living in a Karelian village. The aim of this study is consider how the children self-estimate their ability to speak, understand, read or write Karelian. The research material consists of answers to four questions of my questionnaire at 15th April 2008 at school of Kotkatjärvi. The results of the full questionnaire and the whole revitalisation process of Karelian will be discussed more deeply in my forthcoming doctoral thesis.

\section{Revitalisation of Karelian}

Language revitalisation, as we see it, is a long running process the goals of which are, first, to increase the relative number of speakers and, second, to extend the domains where the language is used. It involves counter balancing forces, such as historical, political and economic ones, which have caused language shift. (Grenoble and Whaley 2006: 13,21.) 
The revitalisation of the Karelian language and culture began quietly amongst the Karelian intelligentsia in the early 1980s. Officially and more openly, the revitalisation started in May 1989 when a conference titled "The Karelians: people, language, culture and economy" was held in Petrozavodsk, the republic's capital. At this conference, a non-governmental cultural association called the Karjalan Rahvahan Liitto (Union of the Karelian people) was founded and resolved to establish a newspaper in Karelian. Karelian became a school subject in autumn 1989. Textbooks and other materials were assiduously published from the early 1990s. A few years later departments of Karelian at Petrozavodsk State University and at the Karelian State Pedagogical University (nowadays Karelian State Pedagogical Academy) were opened. Furthermore, one of the decisions made at the Karelian's conference was to create a standardised written Karelian language, but due to the major differences between the dialects, the conclusion was to start developing two forms of written Karelian. One written form is based on the White Sea Karelian and the second is based on the Olonetsian. Today Lude is also used in the written form and there are some efforts to standardise it, too. In 1998, a Terminological and Orthographic Commission was founded. Since 1991 there have been plenty of normative-juridical efforts, legislative proposals and acts concerning the language question. Twice the Karelian parliament has considered a language law that would make Karelian the republic's second official language along with Russian. Both times, however, parliament rejected this law arguing that Karelian is not developed enough to be an official language. In March 2004, a law on governmental support to the national minority languages (Finnish, Karelian, and Veps) in the Republic of Karelia was proclaimed. (Zaikov 2003.)

Karelians have been revitalising their language for 20 years now. Despite of the revitalisation efforts Karelian still is an endangered language. Both the number of Karelians and those who speak Karelian is declining. According to the 1989 Census, there lived almost 79,000 Karelians in the Karelian ASSR and 51.5\% of them named Karelian as their mother tongue (Klementjev 1991: 163). According to the 2002 census, in the Russian Federation there are over 93,000 Karelians and about 65,500 of them live in the Republic of Karelia. There were around 30,000 Karelians in the Republic of Karelia who mastered their language. The mastery of a language means the ability to speak, read, and write or just talk in 
the given language. That means not even a half of Karelians living in the republic know their native language. (Perepis' 2002.) The fact is that the old native speakers are passing away; the new generations are almost russificated. It's a well known fact that the mother tongue of almost all Karelian children is Russian. It is said that only the grandmothers speak Karelian, while the children do not speak Karelian as their mother tongue. Worse than that, it is said that they do not speak Karelian at all.

\section{Children's knowledge of Karelian}

Since the summer 1995 I have made several field trips to a village Kotkatjärvi (Kotkozero in Russian). Kotkatjärvi is the Karelian village in the Olonetsian area, $100 \mathrm{~km}$ from Petrozavodsk, the capital of the Republic of Karelia. Today, there are about 1,000 people in the village and majority of them are Karelians by nationality (Kareliia entsiklopediia s.v. Kotkozero). Because of my field trips to the village, I am quite familiar with the village itself and its inhabitants. Kotkatjärvi is a prime example of a present-day Karelian village: people have no work and therefore they move to the cities or, men as well as women, run a high risk of becoming alcoholics.

In Kotkatjärvi, a teacher of the Karelian language told me that there are children who can speak it. Also my subjects have said the same thing. I found this information really interesting and that is why I made a case study at the local school in Kotkatjärvi. I was interested in the children's attitudes and thoughts about the Karelian language and its future. And of course, I wanted to find out if these children could speak Karelian or not.

In my questionnaire there were in total 48 questions including background information. The questions were in Russian. Some of the questions were multiple-choice questions, whereas some of them required short written answers. My questionnaire was answered by all those pupils from 5th to 11th class who were at school that day, 15th April 2008. I got in total 63 answers. The children were aged 10-18 years, there were 26 males and $36 \mathrm{fe}-$ males, one person did not report his or her sex. Almost half (30 persons) of the children were born in 1991 and 1992, after that the birth rate has declined all over the Russian Federation.

A question of nationality is complicated in general. Few years ago the Russian Federation promulgated a law, which says that the 
citizens of the Russian Federation do not have to notify a nationality in their passports. According to the Constitution of Russian Federation (Konstitutsiia Rossiiskoi Federatsii glava 2, stat' ia 26), people have the right to decide their own nationality and that is why nationality is not so reliable and significant factor in many cases. However, my questionnaire included the nationality. Only one student did not answer that question, 38 were Karelians and 24 Russians.

What is these children's mother tongue? Majority, exactly three quarters marked Russian as their mother tongue. One quarter marked both Russian and Karelian as their mother tongues. Three children marked Karelian as their mother tongue, but in one of the cases I think this was by mistake, as the other answers did not back it up.

I also asked which language children speak at home. In ten homes, both Karelian and Russian are spoken, in the rest of homes only Russian. I asked if anyone spoke Karelian in their homes. Like I mentioned earlier, it is said that only grandmothers speak Karelian, and this was shown in the replies as well. But more often the mother was mentioned. In half of the homes, the mother speaks Karelian, and I think that is quite good. Also fathers speak Karelian, and in few papers it was said that all family members can speak Karelian. According to these answers, I think that it is not only the grandparents who transfer the language but parents do, too.

And finally to my main question: How did these children estimate their knowledge of Karelian? My question was formulated as follows: How do you estimate your knowledge of Karelian in four the areas: speaking, understanding, writing and reading. There were five possibilities to choose from: not at all, bad, fair, good or fluent. This kind of self-assessment survey may not be very reliable, because the respondents may not have an accurate idea of how well they know the language (Grenoble and Whaley 2002: 164). However, it gives us some information. In this paper, the exact numbers are not very important. Instead of numbers, it is more important to find out generally, if there are children who know the Karelian language.

Here are the facts about the children's answers:

$46 \%$ of the children estimated that

they can speak Karelian fair, good or fluent.

$59 \%$ of the children estimated that

they understand Karelian fair, good or fluent. 
$59 \%$ of the children estimated that

they can read Karelian fair, good or fluent.

$43 \%$ of the children estimated that

they can write Karelian fair, good or fluent.

There is some coherence between these answers. First, those children who are speaking the language at home, but not learning it at school, estimated that their speaking and understanding are better than reading and writing. This was shown also in an opposite setting. Reading and writing in Karelian were at a higher lever with those children who have learnt Karelian at school, but not at home. One of the most important observations is that children, who are speaking Karelian at home and also learning it at school, estimated their knowledge high in all areas. On one hand, this is obviousness; these children use Karelian much more than others. But, on the other hand, this is remarkable from the sociolinguistic point of view. I have realised that among Karelians it is very typical that parents say it is teachers' work to teach Karelian to the children, and of course, the teacher say that it is parents' task to teach Karelian to their children. According to my study, the best result of learning will occur when the school and home are collaborating.

Although my research material is based on the children's self-assessment, the results give us some guidelines. The first and the most important point is that they are children who have knowledge of the Karelian language. Second, there still are parents who can speak and, furthermore, who do speak Karelian. So it is not right or reasonable to blame that all parents do not transmit their language to the next generation. Third, only very few children have a very good knowledge of Karelian, but, in my opinion, so called passive knowledge is better than no knowledge at all. Fourth, when children have learnt language at home, they can speak and understand Karelian better, whereas those children who have learnt language at school, are better in writing and reading. Fifth, to reach a good knowledge of Karelian requires both speaking at home and learning at school.

I already told that home and school alike give different kind of skills. To activate the children's passive knowledge requires help from everyone. It is quite easy to say to the parents and grandparents that they should speak Karelian at home. But we know it is not so easy to put this recommendation into action: it is very difficult to start to speak a language that one was earlier not allowed to speak. 
I think that for activating the use of Karelian of the children there should be much more materials and activities which are directed to young people. In the Republic of Karelia, there have been published several books for small children, also school books are simple enough and childish. Young people are not so interested in poetry and "the good old times" which these poems and short stories mostly tell about. Neither they are not interested in traditional folk songs or other old-peoples-things. Young people need music, rock or rap or something similar. They need movies. They need parties. They need detective stories and other modern literature, magazines, for example.

The school books should be current and related to young people's things, for instance hobbies. The teaching at schools should take advantage of new technologies and possibilities, for instance the Internet.

The parents, however, are in a better position to help with the language learning; they should only talk in their own language to their children. The other means need time and money and, of course, people to do all this. Unfortunately, for example, the Ministry of Education is not very interested in promoting the Karelian language. As an example, Karelian is a voluntary subject at schools, and there is only one or two lessons a week, and even not in every grade neither at every school. It would be the first step to get Karelian as an obligatory subject in all schools of the republic.

\section{Conclusion}

In the title I asked if the children are the future of the Karelian language. According my study I can say yes, they are. I'm, maybe, too positive, but I would like to think that if there is one child who can speak Karelian, there is still hope. As my study shows, there is more than one or two Karelian speaking child in Kotkatjärvi. Of course, Kotkatjärvi is just one village. There are more villages in the Republic of Karelia, and I'm sure that we will find more Karelian speaking children there. But, despite of the fact, that children have some sort of knowledge of language, they need plenty of help and plenty of support so they can become skilful Karelian speakers. 


\section{Address:}

Sanna-Riikka Knuuttila

Karelian Institute

University of Eastern Finland, Joensuu Campus

PL 111

80101 Joensuu

Finland

E-mail: sanna-riikka.knuuttila@uef.fi

\section{References}

L. A. Grenoble and L. J. Whaley (2006) Saving languages. Cambridge: Cambridge University Press.

Kareliia entsiklopediia. Tom 2. Petrozavodsk: PetroPress, 2009.

Klementjev, J. (1991) “Karjalaiset. Vuoden 1989 väestölaskenta”. Carelia 6, 162164.

Konstitutsija Rossiiskoi Federatsii. [Petrozavodsk: Karelija, 2009]

Perepis' 2002. www.perepis2002.ru/index.html?id=17, accessed in 13.01.2005.

Zaikov, Z. (2003) “Karelian language in the Republic of Karelia”. In Esa Anttikoski, ed. Developing written Karelian, 38-45. Joensuu: University of Joensuu.

Kokkuvõte. Sanna-Riikka Knuuttila: Lapsed - karjala keele tulevik? Uurimistöö Karjala külas. Artikkel käsitleb karjala keele oskust ühe Karjala küla koolilaste seas. Karjala keel on ohustatud keel ja seda peetakse n-ö vanade inimeste keeleks. See on põhjus, miks ma tundsin huvi laste karjala keele oskuse vastu. Artikli eesmärk on vaadelda, kuidas lapsed ise hindavad oma oskust rääkida, lugeda ja kirjutada karjala keeles ning sellest keelest aru saada. Uurimusest selgub, et karjala lapsed küll oskavad mingil moel oma pärandkeelt. Selleks, et saavutada ladus keelekasutus, vajavad lapsed oma vanemate, õpetajate ja kogukonna abi ning toetust.

Märksõnad: ohustatud keel, taaselustamine, karjala keel 
